\title{
Looking Through Our Own Barriers to Recognize Our Students' Integrity
}

\author{
William Douglas Woody, PhD \\ Professor, Department of Psychological Sciences \\ University of Northern Colorado
}

\begin{abstract}
Many scholars of ethical teaching recommend that teachers review their own biases and strive to reduce the influence of these biases in their classrooms (e.g., Svinicki \& McKeachie, 2010; Davis, 1993; Boysen \& Vogel, 2009). Teachers and students perceive fairness as necessary for the credibility of academic disciplines as well as departments and instructors (Keith-Spiegel, Tabachnick, \& Allen, 1993; Tabachnick, Keith-Spiegel, \& Pope, 1991), and these concerns apply across academic fields (Woody, 2008b). As teachers of psychology, we should strive to eliminate or reduce the influence of our own extracurricular biases as we choose topics, present material, discuss current events, incorporate class examples, and engage in other inherently persuasive teaching activities (Friedrich \& Douglass, 1998; Svinicki \& McKeachie, 2010; Woody, 2006). Additionally, we should challenge the biases of our students (Boysen \& Vogel, 2009; Boyson, Vogel, Cope, \& Hubbard, 2009; Wolfe \& Spencer, 1996) and seek to perpetuate the disciplinary, university, college, and department goals of increasing our students' awareness of issues and questions in diversity and multicultural education (see American Psychological Association, 2002, 2003; Halonen et al., 2006).

Perhaps most importantly, we should recognize our personal biases, and we should explicitly strive to keep our biases about ethnicity, gender, language, disability, citizenship status (see Thorpe, 2009 for discussion of students' fears of faculty bias), veteran status, socioeconomic status, political ideology, and religion, among other factors, from affecting our views or treatment of students (see e.g., Babad, Inbar, \& Rosenthal

We should strive to eliminate or reduce the influence of our own extracurricular biases as we choose topics, present material, discuss current events, incorporate class examples, and engage in other inherently persuasive teaching activities.
\end{abstract} 1982; Boysen et al., 2009; Boysen \& Vogel,

2009; Sue, Lin, Torino, Capodilupo, \& Rivera, 2009; Svinicki \& McKeachie, 2010), particularly because even a single incident of bias can influence a student's university experience (Samuel, 2004). It is possible to recognize and change our own biases, but these changes require substantial motivation and effort (Devine \& Monteith, 1999). The biases noted previously have received extensive attention in the literature, and I encourage instructors to evaluate these and other prejudices they may have toward students. Particularly, in addition to the previous list, I encourage teachers of psychology to evaluate the cultural biases and their personal biases toward young adults (Bytheway, 1995) as well as the ways that faculty may treat traditional-aged undergraduate students.

The biases related to age and traditional undergraduate students entered my own awareness most saliently when I was a young (i.e., 32) faculty member who, at the time, looked significantly younger than I was. I attended a social reception at a psychological convention, and I had a conversation with a well-known male psychologist. ${ }^{1}$ He appeared extremely impressed to learn the name of my

${ }^{1}$ I note the psychologist was male only to ease my use of pronouns. 
university, and then he proceeded to ask the names of faculty members with whom I studied. When I named faculty who were my scholarly collaborators, he replied, "Woooow, I bet it is VERY interesting to study with those people." His speech was slow, exaggerated, and simplified. He asked me what topics I studied, and my response earned another exaggerated "Oooooh." His speech pattern was patronizing and familiar, but I needed a moment to recognize it. He used the speech pattern of an uncle being shown a new truck by an excited 7-year old nephew. I wondered how I generated such an air of incompetence as to inspire a well-known psychologist to talk to me as though I were a small child, and then I recognized his misperception: he believed me to be an undergraduate. My realization helped me make sense of his words and his speech pattern, particularly given the literature on juvenile ageism, or negative biases toward children (Westman, 1991); since then, however, our conversation has raised larger questions for me.

I describe this event in my classes as an example of negative bias toward children and young adults, and students and colleagues often ask how I responded to his behavior and to his potential slight. I did not say anything at the time. ${ }^{2}$ My thoughts, then and now, did not focus on myself but rather on the intelligent, selfaware, young adults with whom this faculty member works. This person's advanced undergraduate students, many of whom are bound for graduate and professional programs, can serve in the armed forces (and may already be combat veterans), vote, raise families as is typical around the world for adults of traditional college age, and would face adult charges for criminal activity, ${ }^{3}$ but these students face childlike treatment from an influential mentor who may shape their careers and write on their behalf for future education and employment.

These biases against children and young adults have strong foundations in our culture (Westman, 1991). Additionally, emerging adulthood (i.e., from the late teens through the twenties) has gained more support in the literature as a unique phase of life distinct from later adulthood (see e.g., Arnett, 2000; 2004). Older adults may perceive and treat emerging adults as children, and emerging adults may perceive themselves as children (Dickinson, 2010). As teachers of psychology, however, we should challenge biases toward children and young adults as well as the extracurricular effects of these biases in the classroom. Fighting one's biases is difficult, particularly when one challenges biases with strong cultural roots. Additionally, as individuals embedded in a hierarchical system that can devalue students (see Woody, 2004), faculty may find it difficult to recognize their own views. Regardless, I recommend that teachers of psychology strive to recognize, evaluate, and challenge their own stereotypes about age. Several concrete steps exist. First, I recommend that faculty explicitly set adult expectations for their classes and clearly expect students to rise to these standards (see Babad, 1993; Jussim, Madon, \& Chatman, 1994). For a short example, I do not take attendance in my demanding senior-level classes. Instead, when discussing the syllabus on the first day of class, I read from my syllabus that "For every class session, 100 percent attendance and active, appropriate, scholastic senior-level participation is expected." I then note that I will not take attendance and that each student has the freedom and responsibility to make his or her own choices regarding class attendance, participation, and performance. My emphasis on the adult status of students does not mean that I am rigid. This view of my students

${ }^{2}$ Eventually, a passer-by addressed me by title, and our conversation became rather awkward.

${ }^{3}$ Including eligibility for the death penalty in some states. 
also means that I expect them to have complicated and sometimes difficult adult lives and that I remain flexible for the adults in my classes. Throughout the class, I emphasize student responsibility, even as I provide support and guidance as an instructor.

As a second concrete step, I recommend that faculty cease to refer to their students as the "kids" in their classes. As an instructor of mostly upper-division classes, there are very few if any legal children in my classes, and I do not refer to students as "kids." When I teach the psychology of prejudice, we explicitly discuss this decision when we talk about the importance of respect across cultural divisions, including age. Throughout the class, I explicitly and carefully adhere to language that accurately reflects my expectations and my students' responsibilities. I made these decisions in my own teaching in the absence of experimental assessment. I did not know that students noticed this behavior until a convention conversation hour about prejudice in classrooms (Becker, Elliot, Squires, \& Adaoag, 2007). Students talked about the degrees to which they felt inspiration, responsibility, and, perhaps more importantly, respect by the refusal to call them 'kids.'

These issues, however, are not simple. We hope that students of every age undergo development from intellectually curious freshmen to inspired, methodologically aware, better-educated, intellectually curious seniors, and recognition of this developmental process remains critical to our success as teachers (see e.g., Brewer et al., 1993). Of course, we have different scholastic expectations in our introductory or lower-level classes than we do in our upper-division or graduate classes. Interacting with students at different stages of their education raises complex questions. I recognize, for example, that the individual to whom I spoke at the convention may have sought to be more approachable to undergraduates by talking in non-threatening ways; however, one challenge as teachers is to seek approachability with respect. Despite the complexity of these issues, we can find ways to be more approachable without devaluing the young people who require academic support as they develop into scholars. One of our challenges is to see past undergraduates' generally greater needs for instruction (while we seek and recognize exceptional undergraduates; see Woody, 2008a) and instead to see undergraduate students as the fledgling practitioners, scholars, and teachers that we once were. I ask teachers of psychology to undertake a complex endeavor: we should strive to recognize the emerging adulthood of our traditional-aged students without simultaneously devaluing these students as children. Most importantly, we must recognize the integrity of the human beings with whom we work, regardless of their age or other aspects of their

We hope that students of every age undergo

development from intellectually curious freshmen to inspired, methodologically aware, better-educated, intellectually curious seniors, and recognition of this developmental process remains critical to our success as teachers. identities.

As a historian of psychology, I argue we should look past admissions requirements, degree programs, and standardized tests to recognize our earliest historical roots as academics. Throughout history and across cultures, as today in the US, students have endured the hardships of travel, time away from family, challenges of living with limited or nonexistent income or support, and significant financial expenses to sit at the feet of, or study with, faculty (Woody, 2006). The faculty member's obligation is to the student and the student's success. As teachers of psychology, we must recognize students as humans with integrity. Our success comes when our students go beyond us; we must see past our own biases, 
including those biases about age, if we seek to help our students reach their potential.

\section{References}

American Psychological Association. (2002). Ethical principles of psychologists and code of conduct. American Psychologist, 57, 10601074.

American Psychological Association. (2003). Guidelines on multicultural education, training, research, practice, and organizational change for psychologists. American Psychologist, 58, 377-402.

Arnett, J. J. (2000). Emerging adulthood: A theory of development from the late teens through the twenties. American Psychologist, 55, 469-480.

Arnett, J. J. (2004). Emerging adulthood: The winding road from the late teens through the twenties. New York, NY: Oxford University Press.

Babad, E. (1993). Pygmalion: 25 years after interpersonal expectations in the classroom. In P. D. Blanck (Ed.), Interpersonal expectations: Theory, research, and applications (pp. 125-153). New York, NY: Cambridge University Press.

Babad, E. Y., Inbar, J., \& Rosenthal, R. (1982). Teachers' judgments of students'potential as a function of teachers' susceptibility to biasing information. Journal of Personality and Social Psychology, 42, 541-547.

Becker, S., Elliot, J., Squires, L., \& Adaoag, M. (2007). Minority students speak out: Messages to faculty about the college classroom experience. Rocky Mountain Psychological Association Convention, Denver, CO. RMPA Diversity Symposium.

Boysen, G. A., \& Vogel, D. L. (2009). Bias in the classroom. Types, frequencies, and responses. Teaching of Psychology, 36, 12-17.
Boysen, G. A., Vogel, D. L., Cope, M. A., \& Hubbard, A. (2009). Incidents of bias in college classrooms: Instructor and student perceptions. Journal of Diversity in Higher Education, 2, 219-231.

Brewer, C. L., Hopkins, J. R., Kimble, G. A., Matlin, M. W., McCann, L. I., McNeil, O. V., et al. (1993).

Curriculum. In T. V. McGovern (Ed.), Handbook for enhancing undergraduate education in psychology (pp. 161-182). Washington, D.C.: American Psychological Association.

Bytheway B. (2005). Ageism. Bristol, PA: Open University Press.

Davis, B. G. (1993). Tools for teaching. San Francisco, CA: JosseyBass.

Devine, P. G., \& Monteith, M J. (1999). Automaticity and control in stereotyping. In S. Chaiken \& Y. Trope (Eds.), Dual-process theories in social psychology (pp. 339-360). New York, NY: Guilford.

Dickinson, A. (July 28, 2010). Ask Amy: College-age "kids" just finding their way. Retrieved August 23, 2010 from http://www. philly.com/inquirer/maga zine/20100728_Ask_Amy_Collegeage_kids__just_finding_their_way.h tml

Friedrich, J., \& Douglass, D. (1998). Ethics and the persuasive enterprise of teaching psychology. American Psychologist, 53, 549-562.

Halonen, J. S., Appleby, D. C., Brewer, C. L., Buskist, W., Gillem, A. R., Halpern, D., et al. (2006). APA guidelines for the undergraduate psychology major. Washington, D.C.: American Psychological Association. 
J ussim, L., Madon, S., \& Chatman, C. (1994). Teacher expectations and student achievement: Self-fulfilling prophecies, biases, and accuracy. In L. Heath, R. S. Tindale, J. Edwards, E. J. Posavac, F. B. Bryant, E. Henderson-King, Y. Suarez-Balcazar, \& J. Myers (Eds.), Applications of heuristics and biases to social issues (pp. 303-334). New York, NY: Plenum Publishing.

Keith-Spiegel, P. C., Tabachnick, B. G., \& Allen, M. (1993). Ethics in academia: Students' views of professors' actions. Ethics and Behavior, 3, 149-162.

Samuel, E. (2004). Racism in peergroup interactions: South Asian students' experiences in Canadian academe. Journal of College Student Development, 45, 407-424.

Sue, D. W., Lin, A. I., Torinio, G. C., Capodilupo, C. M., \& Rivera, D. P. (2009). Racial microaggressions and difficult dialogs on race in the classroom. Cultural Diversity and Ethnic Minority Psychology, 15,183190.

Svinicki, M., \& McKeachie, W. J. (2010). McKeachie's teaching tips: Strategies, research, and theory for college and university teachers ( $13^{\text {th }}$ ed.). Belmont, CA: Cengage Learning.

Tabachnick, B. G., Keith-Spiegel, P., \& Pope, K. S. (1991). Ethics of teaching: Beliefs and behaviors of psychologists as educators. American Psychologist, 46, 506-515.

Thorpe, H. (2009). Just like us: The true story of four Mexican girls coming of age in America. New York: Scribner.

Westman, J. C. (1991). Juvenile ageism: Unrecognized prejudice and discrimination against the young. Child Psychiatry and Human

Development, 21, 237-256.
Wolfe, C. T., \& Spencer, S. J. (1996). Stereotypes and prejudice: Their overt and subtle influence in the classroom. American Behavioral Scientist, 40, 176-185.

Woody, W. D. (2004). Universities, psychology departments, and the treatment of graduate students. In W. Buskist, V. W. Hevern, B. K. Saville, \& T. Zinn (Eds.), Essays from E-xcellence in teaching, (vol. 3). Electronic book: Society for the Teaching of Psychology. Available at http://teachpsych. lemoyne.edu/teach psych/eit/eit2003/index.htm

Woody, W. D. (2006). Ethical teaching. In W. Buskist, \& S. F. Davis (Eds.), Handbook of the Teaching of Psychology (pp. 221-227). Malden, MA: Blackwell Publishing.

Woody, W. D. (2008a).

Collaboration: Faculty perspective. In R. Miller, R. Rycek, E. Balcetis, S.

Barney, B. Beins, S. Burns, R. Smith, \& M. E. Ware, (Eds.), Developing, promoting, and sustaining the undergraduate research experience in psychology (pp. 215-219).

Electronic book: Society for the Teaching of Psychology. Available at http://teachpsych.org/resources/ebooks/ur2008/5-2\%20Woody.pdf

Woody, W. D. (2008b). Learning from the codes of academic disciplines. New Directions for Higher Education [Special Issue: Practical Approaches to Ethics for Colleges and Universities], 36, 39-54. 
William Douglas Woody earned his PhD in 1999 from Colorado State University. He taught at the University of Wisconsin - Eau Claire for two and a half years and is currently Professor of Psychological Sciences at the University of Northern Colorado. His research interests include the teaching of psychology, psychology and law, and the history of psychology. He has received numerous college, university, and national teaching awards, including the Wilbert J. McKeachie Teaching Excellence Award from the Society for the Teaching of Psychology (APA Division Two). Additionally, he has been named Best Professor by the students at two of the three universities at which he has taught.

Volume $5 \bullet 2010$ 